\title{
Effect of $\mathrm{TiB}_{2}$ Particles on Microstructure of 7075 Al Alloy in Semi-Solid State Near Liquidus
}

\author{
Gui-sheng Gan ${ }^{1, *}$, Huai-shan Wang ${ }^{1}$, Guo-qi Meng ${ }^{1}$ and Bin Yang ${ }^{2}$ \\ ${ }^{1}$ Chongqing Municipal Engineering Research Center of Institutions of Higher Education \\ for Special Welding Materials and Technology, Chongqing 400054, China \\ ${ }^{2}$ State Key Laboratory for Advanced Metals and Materials, University of Science \& Technology, \\ Beijing, Beijing 100083, China
}

$\mathrm{TiB}_{2} / 7075 \mathrm{Al}$ matrix composites were formed by in situ reaction, and effect of the $\mathrm{TiB}_{2}$ particles content on microstructure of $7075 \mathrm{Al}$ alloy in semi-solid state near liquidus were investigated. The results have shown that the average grain size decreased with increased the amount of $\mathrm{TiB}_{2}$, and the microstructure became uniform rosette grains. The morphology of grains became big dendrite grains when the particles content were over 4.5 mass $\%$. Globular grains of $7075 \mathrm{Al}$ alloy whose size reached $94 \mu \mathrm{m}$ can be got for $7.5 \mathrm{~min}$ at $630^{\circ} \mathrm{C}$. The minimum grain size of 3 mass $\% \mathrm{TiB}_{2} / 7075,4.5$ mass $\% \mathrm{TiB}_{2} / 7075$ and 9 mass $\% \mathrm{TiB}_{2} / 7075 \mathrm{Al}$ matrix composites at $630^{\circ} \mathrm{C}$ were $88 \mu \mathrm{m}, 51 \mu \mathrm{m}$ and $69 \mu \mathrm{m}$ for $30 \mathrm{~min}$, $20 \mathrm{~min}$ and $50 \mathrm{~min}$, respectively. The $\mathrm{TiB}_{2}$ particles located in the grain boundary can hinder the $\mathrm{Al}$ atoms from diffusing within the semi-solid state of the $7075 \mathrm{Al}$ alloy and restrain $\alpha$-Al phase growth, but it can be conducive to improve the stability of semi-solid slurry in near-liquidus thixoforming. [doi:10.2320/matertrans.M2014447]

(Received December 4, 2014; Accepted August 24, 2015; Published October 9, 2015)

Keywords: in situ reaction, 7075 Al alloy, semi-solid, globular grain, TiB, particles

\section{Introduction}

Semisolid forming (SSM) was a near-net-shape forming technology for metals and alloys developing at MIT during the 1970s. ${ }^{1,2}$ SSM was considered as one of the most prospective materials processing technologies in 21 century. The key issue of semi-solid forming is how to fabricate the proper slurry containing the non-dendritic microstructure. ${ }^{3)}$ Semisolid slurry of thixocasting is prepared by reheating at the solid state, which need no stirring.

$7075 \mathrm{Al}$ alloy have been widely used as structural materials in aeronautical industries due to their attractive comprehensive properties, such as low density, high strength, ductility, toughness. Previous work has shown that SSM processing were appropriate for $7075 \mathrm{Al}$ alloy, including rheocasting ${ }^{4-9)}$ and thixocasting. ${ }^{10-12)}$ The author also studied the effect of $\mathrm{TiB}_{2}$ on the semi-solid microstructure of $7075 \mathrm{Al}$ alloy in the rheocasting process. ${ }^{13-17)}$ But the effect of the $\mathrm{TiB}_{2}$ particles on microstructure of $7075 \mathrm{Al}$ alloy slurry by thixocasting in semi-solid state near liquidus has no in-depth study. The present work is, combining with in-situ reaction, to prepare $7075 \mathrm{Al}$ alloy semi-solid slurry by reheating at semisolid temperature after adding $\mathrm{TiB}_{2}$ particles.

\section{Experimental}

The material we studied was a commercial wrought 7075 $\mathrm{Al}$ alloy. The liquidus and solidus temperature of the alloy were $639.1^{\circ} \mathrm{C}$ and $477.4^{\circ} \mathrm{C}$, respectively. ${ }^{13)}$ The chemical composition of 7075 alloy used in present study was Al5.52 mass $\% \mathrm{Zn}-2.36$ mass $\% \mathrm{Mg}-1.51$ mass $\% \mathrm{Cu}-0.18$ mass $\% \mathrm{Si}-$ 0.26 mass $\% \mathrm{Fe}-0.15$ mass $\% \mathrm{Mn}-0.25$ mass $\% \mathrm{Cr} . \mathrm{K}_{2} \mathrm{TiF}_{6}$ (mass $>$ $97 \%$ ) and $\mathrm{KBF}_{4}$ (mass $>97 \%$ ) mixture were put into the molten of 7075 alloy at $850^{\circ} \mathrm{C}$. After stirring at the same temperature for about $30 \mathrm{~min}$ and degassing by using $\mathrm{C}_{2} \mathrm{Cl}_{6}$,

*Corresponding author, E-mail: ggs@cqut.edu.cn the molten of $\mathrm{TiB}_{2} / 7075 \mathrm{Al}$ composites and $7075 \mathrm{Al}$ alloy at $720^{\circ} \mathrm{C}$ was casted in $15-\mathrm{mm}$ diameter's graphite mould. Casts were cut out respectively $\mathrm{n}$ height of $8 \mathrm{~mm}$, and then these were put into the holding furnace at $630^{\circ} \mathrm{C}$. Finally, the samples can be obtained by immediately quenching with the different holding time.

The grain size and area of the primary solid phase were analyzed statistically by a quantitative image analysis system. A close observation of microstructure can be given by average gain diameter $D=2(A / \pi)^{1 / 2}$ and shape factor $F=$ $4 \pi A / P^{2}$, where $A$ and $P$ are average area and average perimeter of primary phase, respectively.

\section{Results and Discussion}

\subsection{Influence of the $\mathrm{TiB}_{2}$ particles content on micro- structure of $7075 \mathrm{Al}$ alloy}

Figure 1 shows the microstructure of $3 \%$ (in mass, similarly hereinafter) $\mathrm{TiB}_{2} / 7075$ and $4.5 \% \mathrm{TiB}_{2} / 7075$, $6 \% \mathrm{TiB}_{2} / 7075$ and $9 \% \mathrm{TiB}_{2} / 7075 \mathrm{Al}$ matrix composites after pouring into graphite mould at $720^{\circ} \mathrm{C}$. After adding $3 \% \mathrm{TiB}_{2}$, the microstructure becomes uniform rosette grains, and the grain size shows a decreasing tendency with increasing of $\mathrm{TiB}_{2}$ particles. The morphology of grains become big dendrite grains after adding $6 \% \mathrm{TiB}_{2} .9 \% \mathrm{TiB}_{2} / 7075 \mathrm{Al}$ matrix composites is also mainly composed of the dendrite grains, but the grain size is smaller than $6 \% \mathrm{TiB}_{2} / 7075 \mathrm{Al}$ matrix composites.

Quested $^{18-21)}$ found that the grain size shown a minimum as average particle diameter was decreased. Although it shown a different experiment result of minimum grain size and its average particle diameter, the tendencies are generally the same. As the average particle diameter is decreased, the number of particles must increase, and this leads to a decrease in grain size. But smaller particles give intrinsically less good refinement as their activation at greater undercooling leads to faster growth. It is found that smaller particle 

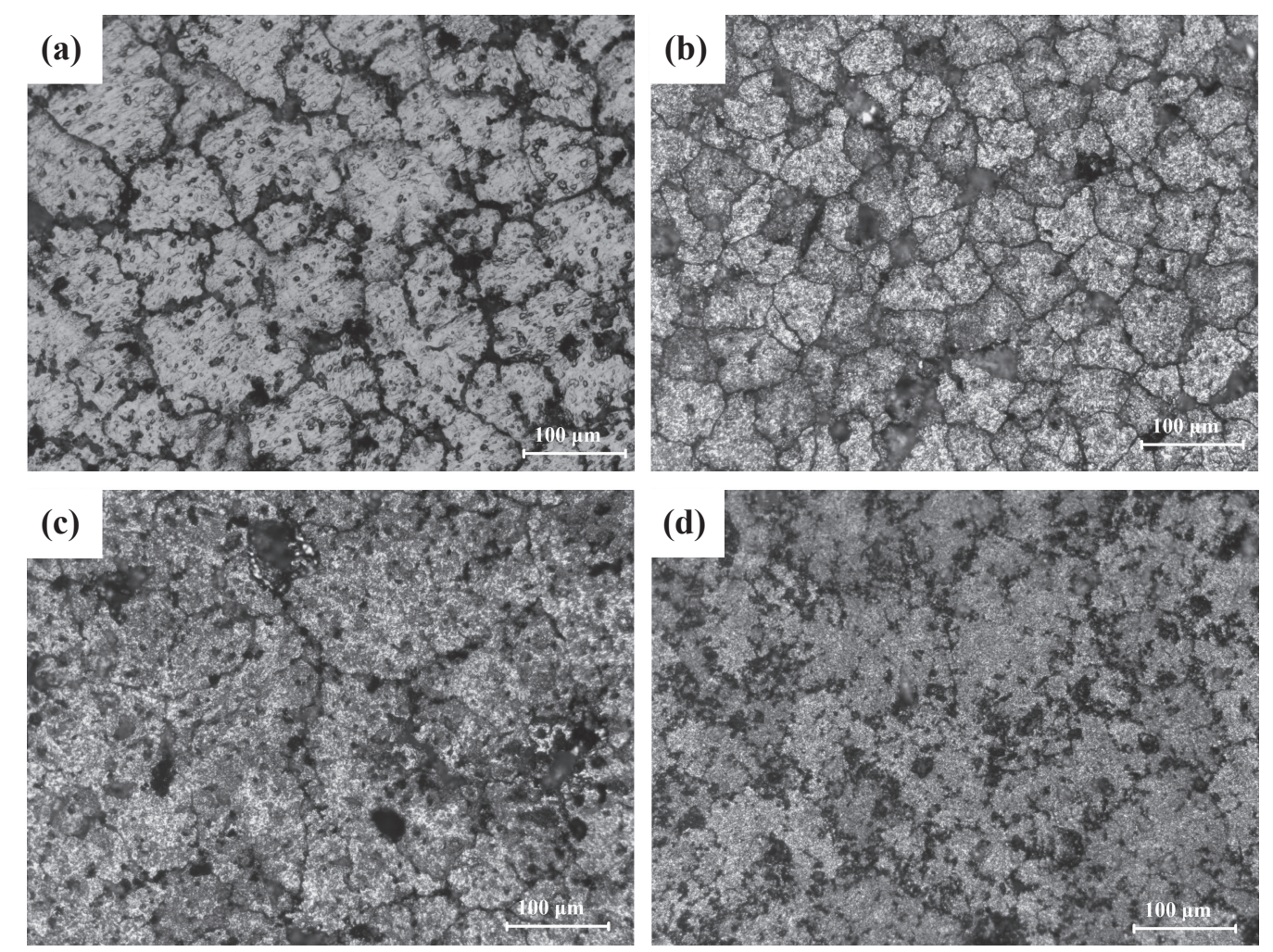

Fig. 1 The microstructure of the solid $\mathrm{TiB}_{2} / 7075 \mathrm{Al}$ matrix composites; (a) $3 \% \mathrm{TiB}_{2} / 7075$, (b) $4.5 \% \mathrm{TiB}_{2} / 7075$, (c) $6 \% \mathrm{TiB}_{2} / 7075$, (d) $9 \% \mathrm{TiB}_{2} / 7075$.

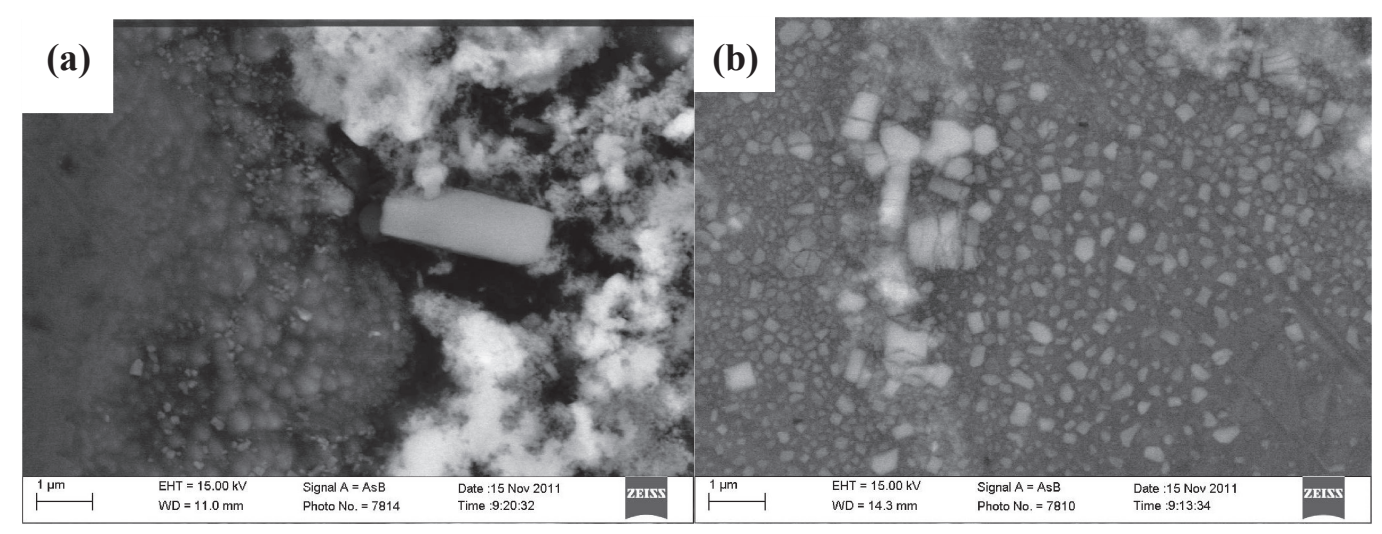

Fig. $2 \mathrm{SEM}$ images of $\mathrm{TiB}_{2}$ particles in as-cast aluminum based composite materials; (a) $3 \% \mathrm{TiB}_{2} / 7075$, (b) $9 \% \mathrm{TiB}_{2} / 7075$.

gives larger grain size if the number of particles is held constant. Particles larger than $\sim 1 \mu \mathrm{m}$ are mostly active, while those smaller than $\sim 0.5 \mu \mathrm{m}$ are mostly inactive. ${ }^{19)}$

The micrograph of $\mathrm{TiB}_{2}$ particles in the $\mathrm{TiB}_{2} / 7075 \mathrm{Al}$ matrix composites is as shown in Fig. 2. Most $\mathrm{TiB}_{2}$ particles reach about $900 \sim 1400 \mathrm{~nm}$ in $3 \% \mathrm{TiB}_{2} / 7075$ composites, even individual up to $2000 \mathrm{~nm}$. Large size of $\mathrm{TiB}_{2}$ particles are distributed in grain boundary area, and a large number of scattered small $\mathrm{TiB}_{2}$ particles with size of $100 \sim 400 \mathrm{~nm}$ are irregular polygon near the boundary inside the nucleus in $9 \% \mathrm{TiB}_{2} / 7075$ composites. Tiny $\mathrm{TiB}_{2}$ particles are engulfed easily in the interface, bringing about the pushing of $\mathrm{TiB}_{2}$ particles. More active $\mathrm{TiB}_{2}$ particles and much less small $\mathrm{TiB}_{2}$ particles can be found in $4.5 \% \mathrm{TiB}_{2} / 7075$ composites, so the grain size is the smallest, comparing with $9 \% \mathrm{TiB}_{2} /$ 7075 composites.
The XRD of $\mathrm{TiB}_{2} / 7075$ and the area scanning of $3 \% \mathrm{TiB}_{2} /$ 7075 composites are listed as shown in Fig. 3(a) and (b) (h), respectively. It can be seen that the microstructure consists of $\mathrm{Al}$ and $\mathrm{TiB}_{2}$ phases, and no other phase can be found. At the same time, the peak intensity of $\mathrm{TiB}_{2}$ became more intense with the increasing of $\mathrm{TiB}_{2}$. The results show that the elements of $\mathrm{Mg}, \mathrm{Cu}$ and $\mathrm{Zn}$ to be determined are homogeneously distributed in samples. Ti elements and B elements mainly concentrate on the grain boundary, but some Ti elements and $\mathrm{B}$ elements distribute in the grain from Fig. 3(f) and (g) which is to say that some $\mathrm{TiB}_{2}$ particles can play as the stable nucleus during solidification.

\subsection{Influence of the holding time on microstructure of $7075 \mathrm{Al}$ alloy in semi-solid state near liquidus}

Figure 4 shows the microstructure of the solid $7075 \mathrm{Al}$ 

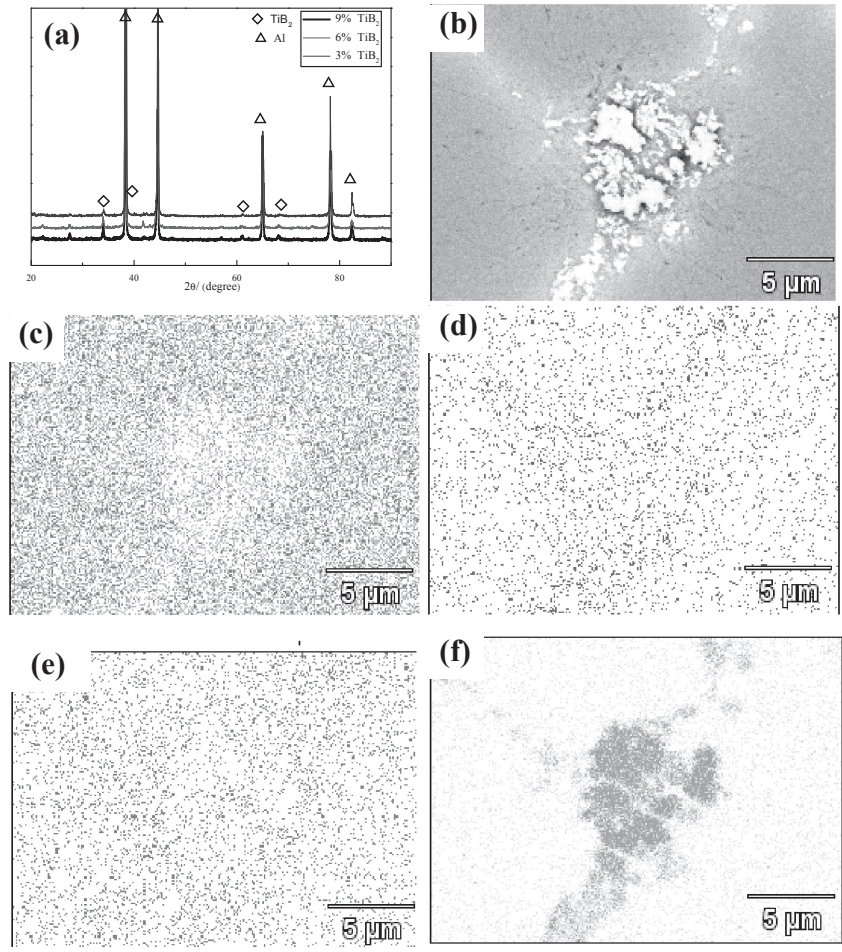

(g)

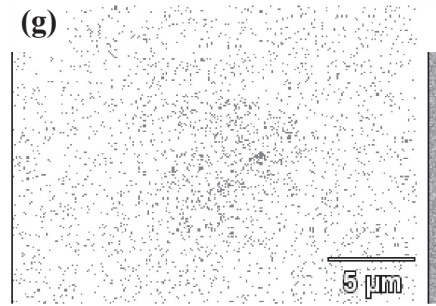

(h)

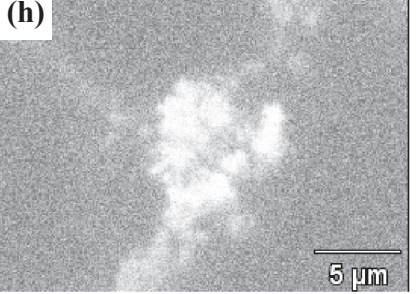

Fig. 3 The XRD of $\mathrm{TiB}_{2} / 7075$ (a) and the area scanning of $3 \% \mathrm{TiB}_{2} / 7075$ composites. The scanning area (b); the distribution of $\mathrm{Mg}(\mathrm{c}), \mathrm{Cu}(\mathrm{d}), \mathrm{Zn}$ (e), Ti (f), B (g), Al (h).

alloy with the different holding time at $630^{\circ} \mathrm{C}$ which is near liquidus in semi-solid state, the maximum grain size is about $250 \mu \mathrm{m}$ of the solid $7075 \mathrm{Al}$ alloy. The branch of rosette grains begins to melt increasing gradually with time, and $\alpha$ $\mathrm{Al}$ grains contract to sphere because spherical surface has the smallest surface energy. It can be got good globular grains for $7.5 \sim 10 \mathrm{~min}$. The mean grain size can reach $94 \mu \mathrm{m}$, and the shape factor can reach 0.65 and 0.78 for 7.5 and $10 \mathrm{~min}$, respectively.

The magnified microstructure of the solid $7075 \mathrm{Al}$ alloy with the different holding time at $630^{\circ} \mathrm{C}$ are shown in Fig. 5 . The dendrite structures of $\alpha$-Al grains melt to form globular grain with holding $7.5 \mathrm{~min}$, and the very small grain exists on the grain boundary. After holding $10 \mathrm{~min}$, globular grain melt to form the melt because the liquid fraction at $630^{\circ} \mathrm{C}$ is about $73.05 \%$. We can see very small grain around globular grain in Fig. 5(d), which is entirely different from small grain with holding $7.5 \mathrm{~min}$.

The microstructure evolution of $7075 \mathrm{Al}$ alloy semi-solid slurry contains three parts: the phenomenon of necking and remelting of dendrite grains can be found at first, then rosette grains melt and shrink into the globular grain, finally the globular grains begin to melt with increasing of the holding time because of no stable crystal nucleus. This is to say that the holding time control is the key factor in near-liquidus thixoforming.

\subsection{Influence of the $\mathrm{TiB}_{2}$ particles content and the holding time on microstructure of $7075 \mathrm{Al}$ alloy in semi-solid state near liquidus}

$\alpha$-Al phase of big rosette grain begin to fuse, small dendrite grains begin to grow up at $630^{\circ} \mathrm{C}$ for $20 \mathrm{~min}$ in Fig. 6. The microstructure becomes uniform rosette grains in $3 \% \mathrm{TiB}_{2} / 7075 \mathrm{Al}$ matrix composites, but it can be get semisolid microstructure in $4.5 \% \mathrm{TiB}_{2} / 7075 \mathrm{Al}$ matrix composites whose mean grain size and shape factor can reach $51 \mu \mathrm{m}$ and 0.68 , respectively. It can be seen that the grains are elongated in $6 \% \mathrm{TiB}_{2} / 7075$ aluminum matrix composites, and the grain boundary of $9 \% \mathrm{TiB}_{2} / 7075$ aluminum matrix composites gets wider. After holding $25 \mathrm{~min}$, the microstructure becomes uniform globular grain in $3 \% \mathrm{TiB}_{2} / 7075$ and $4.5 \% \mathrm{TiB}_{2} / 7075$ aluminum matrix composites, the mean grain size and shape factor can reach $94 \mu \mathrm{m}$ and $84 \mu \mathrm{m}, 0.71$ and 0.78 , respectively.

The microstructures of $\mathrm{TiB}_{2} / 7075 \mathrm{Al}$ composite samples have similar effect rules after held for $30 \mathrm{~min}$ in Fig. 7. The mean grain size and shape factor of $3 \% \mathrm{TiB}_{2} / 7075$ and $4.5 \% \mathrm{TiB}_{2} / 7075$ aluminum matrix composites can reach $88 \mu \mathrm{m}$ and $81 \mu \mathrm{m}, 0.67$ and 0.72 , respectively.

Dendrite grains can be found only in $6 \% \mathrm{TiB}_{2} / 7075 \mathrm{Al}$ matrix composites after being held for $35 \mathrm{~min}$, and it can be get semi-solid microstructure in $9 \% \mathrm{TiB}_{2} / 7075 \mathrm{Al}$ matrix composites whose mean grain size and shape factor can reach $82 \mu \mathrm{m}$ and 0.60 , respectively. The mean grain size and shape factor of $3 \% \mathrm{TiB}_{2} / 7075$ and $4.5 \% \mathrm{TiB}_{2} / 7075 \mathrm{Al}$ matrix composites can reach $114 \mu \mathrm{m}$ and $98 \mu \mathrm{m}, 0.70$ and 0.67 , respectively.

The mean grain size of $3 \% \mathrm{TiB}_{2} / 7075,4.5 \% \mathrm{TiB}_{2} / 7075$ and $9 \% \mathrm{TiB}_{2} / 7075$ aluminum matrix composites can reach $111 \mu \mathrm{m}, 99 \mu \mathrm{m}$ and $69 \mu \mathrm{m}$, respectively, the shape factor can reach $0.76,0.78$ and 0.66 for $50 \mathrm{~min}$, respectively. The mean grain size and the shape factor of $9 \% \mathrm{TiB}_{2} / 7075 \mathrm{Al}$ matrix composites can reach $111 \mu \mathrm{m}$ and 0.72 , respectively for $60 \mathrm{~min}$.

Table 1 is the formation time and the grain size of globular grain at $630^{\circ} \mathrm{C} .4 .5 \% \mathrm{TiB}_{2} / 7075 \mathrm{Al}$ matrix composites are easier to from globular grain because the original microstructure is uniform rosette grains and the mean grain size is the smallest. It needs only about $20 \mathrm{~min}$ to from globular grain and the minimum grain size are about $51 \mu \mathrm{m}$. Whereafter, globular grains begin to grow, but the mean grain size is no significant change from $35 \mathrm{~min}$ to $50 \mathrm{~min}$.

The change of the shape factor with the holding time are not obvious from 0.67 to 0.78 . But the globular grains become rounder in the process of growth from minimum grain to maximum grain.

As we know, $\mathrm{TiB}_{2}$ has high melting point and is thermodynamically stable. The $\mathrm{TiB}_{2}$ particles located in the grain boundary can hinder the $\mathrm{Al}$ atoms from diffusing within the semi-solid state of the $7075 \mathrm{Al}$ alloy, and restrain $\alpha$-Al phase growth. Therefore, it need more time to form globular grain after adding $\mathrm{TiB}_{2}$ particles, comparing with $7075 \mathrm{Al}$ alloy. The minimum grain size of $3 \% \mathrm{TiB}_{2} / 7075,4.5 \% \mathrm{TiB}_{2} /$ 7075 and $9 \% \mathrm{TiB}_{2} / 7075 \mathrm{Al}$ matrix composites are $88 \mu \mathrm{m}$, 

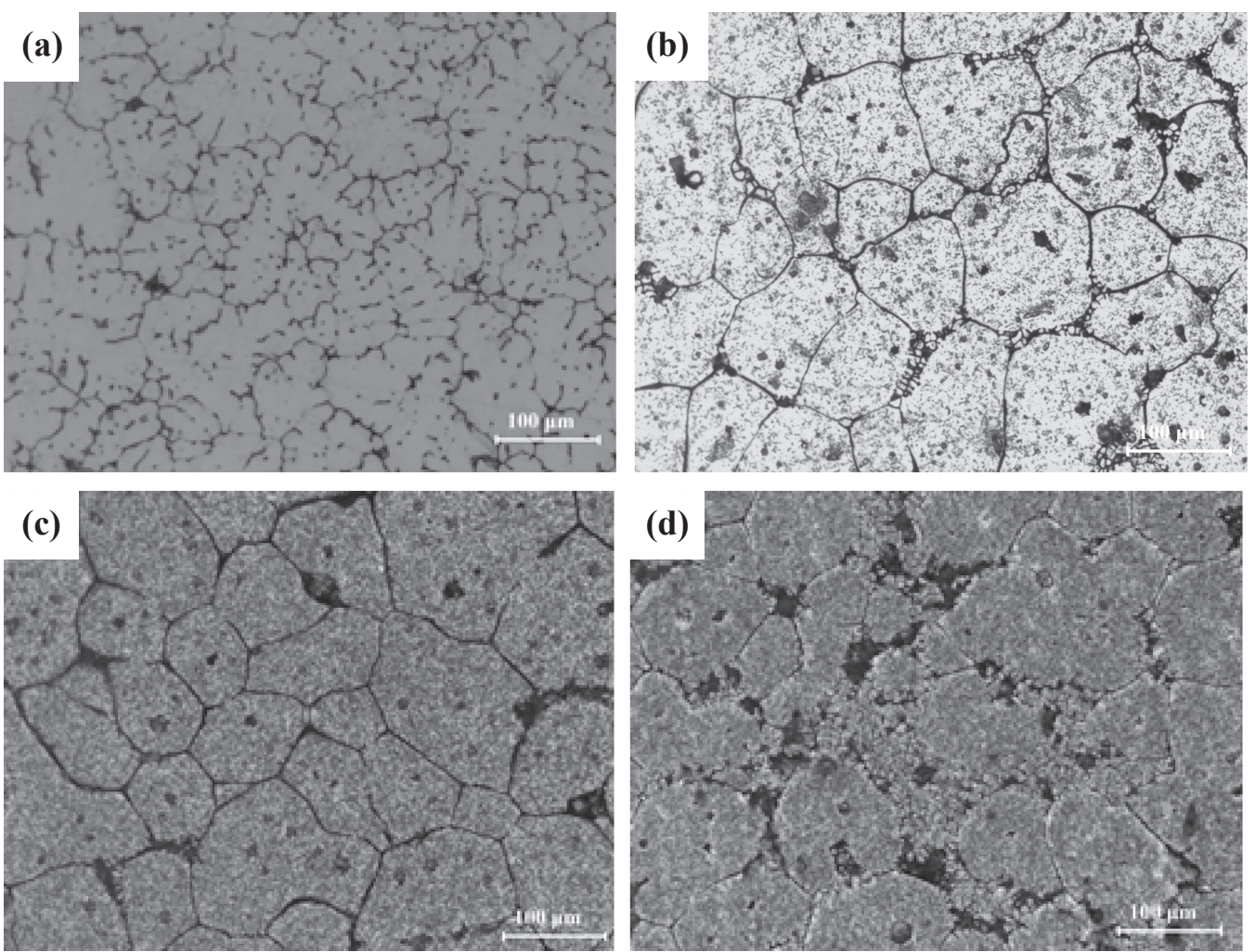

Fig. 4 The microstructure of the solid $7075 \mathrm{Al}$ alloy with the different holding time at $630^{\circ} \mathrm{C}$; (a) $0 \mathrm{~min}$, (b) $7.5 \mathrm{~min}$, (c) $10 \mathrm{~min}$, (d) $15 \mathrm{~min}$.
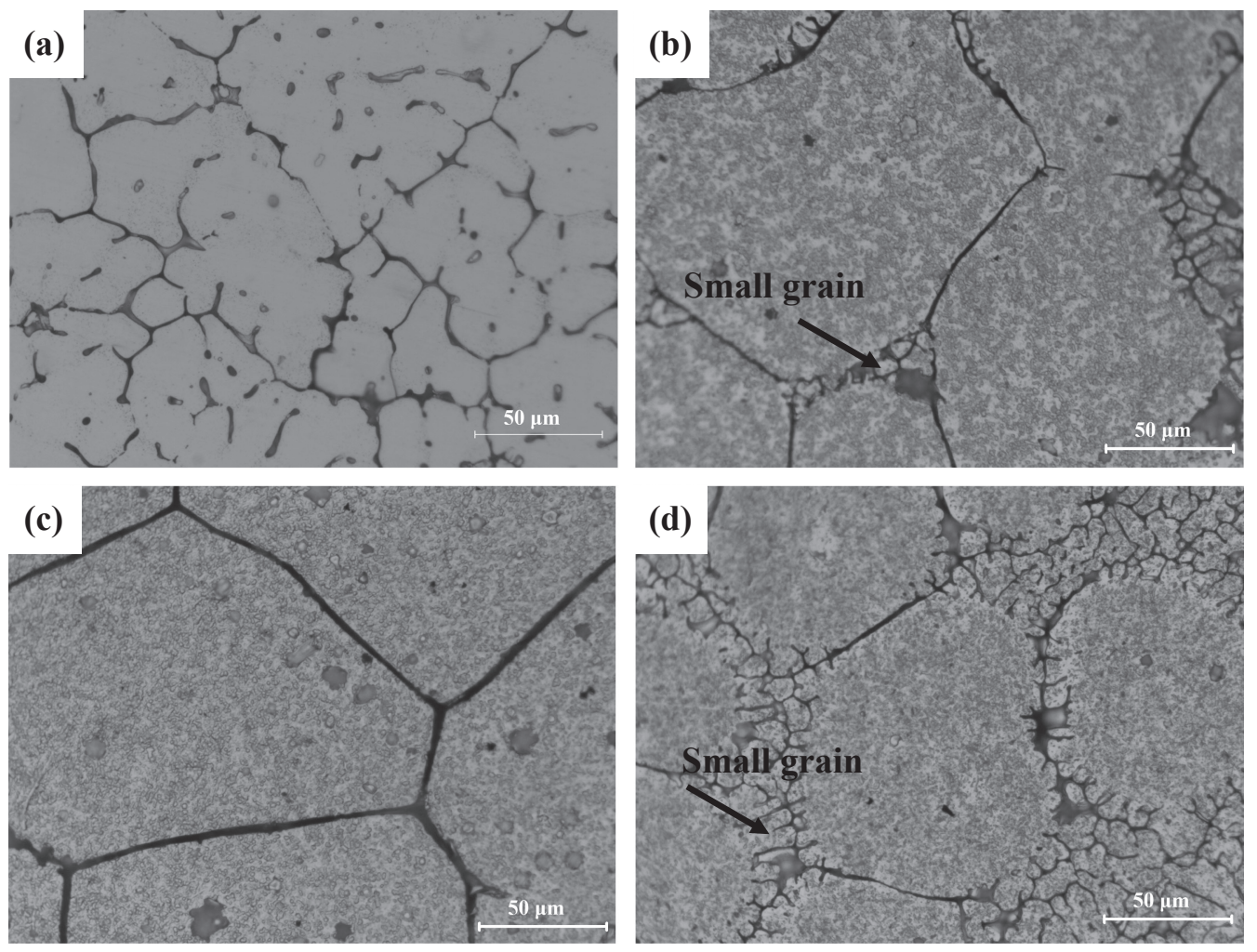

Fig. 5 The magnified microstructure of the solid $7075 \mathrm{Al}$ alloy with the different holding time at $630^{\circ} \mathrm{C}$; (a) $0 \mathrm{~min}$, (b) $7.5 \mathrm{~min}$, (c) $10 \mathrm{~min}$, (d) $15 \mathrm{~min}$.

$51 \mu \mathrm{m}$ and $69 \mu \mathrm{m}$, respectively. Maybe it need more time to get the globular grain in the experiment because dendrite grains of $6 \% \mathrm{TiB}_{2} / 7075 \mathrm{Al}$ matrix composites is the biggest size in all $\mathrm{TiB}_{2} / 7075 \mathrm{Al}$ matrix composites. The micro- structure evolution mechanism of the solid $\mathrm{TiB}_{2} / 7075 \mathrm{Al}$ matrix composites with the different holding time at $630^{\circ} \mathrm{C}$ is proposed and schematically shown in Fig. 8. With increasing holding time, on one hand, some contiguous grains merge 

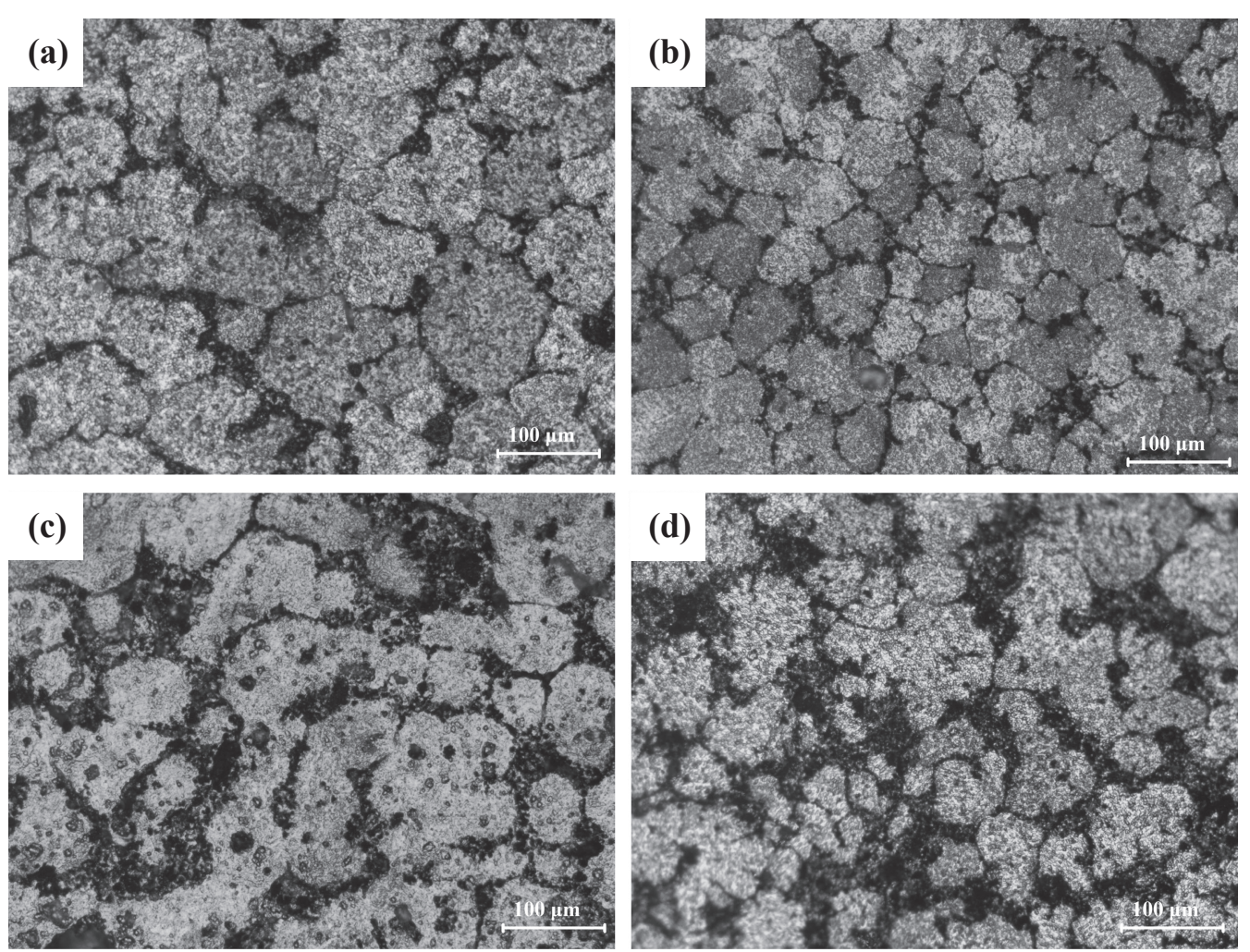

Fig. 6 The microstructure of the solid $\mathrm{TiB}_{2} / 7075 \mathrm{Al}$ matrix composites at $630^{\circ} \mathrm{C}$ for $20 \mathrm{~min}$; (a) $3 \% \mathrm{TiB}_{2} / 7075$, (b) $4.5 \% \mathrm{TiB}_{2} / 7075$, (c) $6 \% \mathrm{TiB}_{2} / 7075$, (d) $9 \% \mathrm{TiB}_{2} / 7075$.
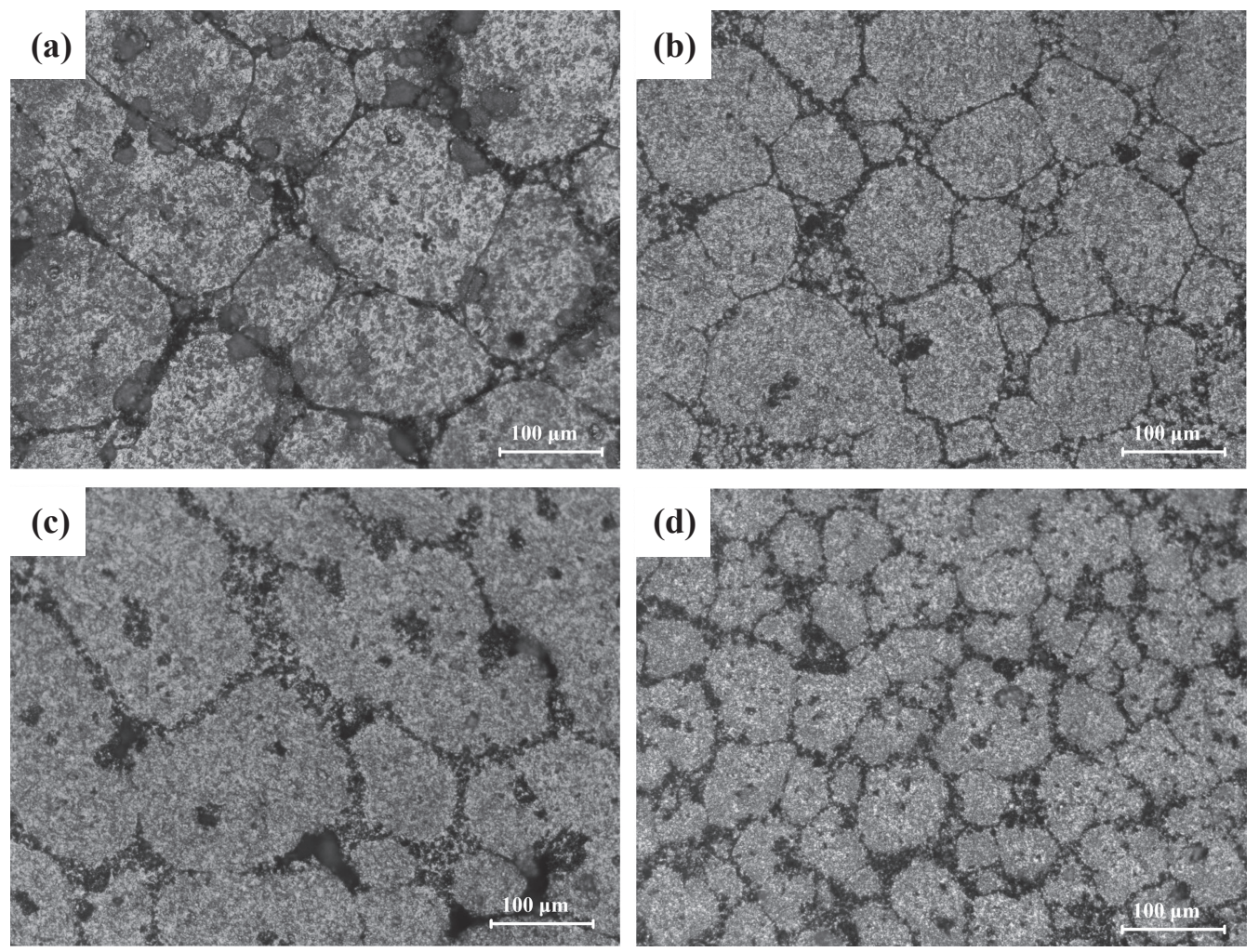

Fig. 7 The microstructure of the solid $\mathrm{TiB}_{2} / 7075 \mathrm{Al}$ matrix composites at $630^{\circ} \mathrm{C}$ for $30 \mathrm{~min}$; (a) $3 \% \mathrm{TiB}_{2} / 7075$, (b) $4.5 \% \mathrm{TiB}_{2} / 7075$, (c) $6 \% \mathrm{TiB}_{2} / 7075$, (d) $9 \% \mathrm{TiB}_{2} / 7075$.

into some bigger grains by coalescence. On the other hand, Ostwald ripening occurs: small grains disappear in favor of bigger grains by diffusion through the solid phase because of the reduction of surface energy and overlapped solution fields of neighboring grains. So the number of grains decreases and their mean grain size increases, with increasing holding time. ${ }^{21)}$ Grains no longer melt at $630^{\circ} \mathrm{C}$ because of $\mathrm{TiB}_{2}$ particles as the stable nucleus. This is to say that $\mathrm{TiB}_{2}$ 
Table 1 Formation time, grain size and shape factor of globular grain at $630^{\circ} \mathrm{C}$.

\begin{tabular}{|c|c|c|c|c|c|c|c|}
\hline \multirow{2}{*}{ Composites } & \multirow{2}{*}{$\begin{array}{c}\begin{array}{c}\text { Globular } \\
\text { grain }\end{array} \\
\begin{array}{c}\text { Formation } \\
\text { time } / \mathrm{min}\end{array}\end{array}$} & \multicolumn{3}{|c|}{ Minimum grain } & \multicolumn{3}{|c|}{ Maximum grain } \\
\hline & & $\begin{array}{c}\text { Size/ } \\
\mu \mathrm{m}\end{array}$ & $\begin{array}{l}\text { Shape } \\
\text { factor }\end{array}$ & $\begin{array}{c}\text { Time/ } \\
\text { min }\end{array}$ & $\begin{array}{c}\text { Size/ } \\
\mu \mathrm{m}\end{array}$ & $\begin{array}{l}\text { Shape } \\
\text { factor }\end{array}$ & $\begin{array}{c}\text { Time/ } \\
\text { min }\end{array}$ \\
\hline $3 \% \mathrm{TiB}_{2} / 7075$ & 25 & 88 & 0.67 & 30 & 111 & 0.76 & 50 \\
\hline $4.5 \% \mathrm{TiB}_{2} / 7075$ & 20 & 51 & 0.68 & 20 & 99 & 0.78 & 50 \\
\hline $9 \% \mathrm{TiB}_{2} / 7075$ & 35 & 69 & 0.66 & 50 & 111 & 0.72 & 60 \\
\hline
\end{tabular}

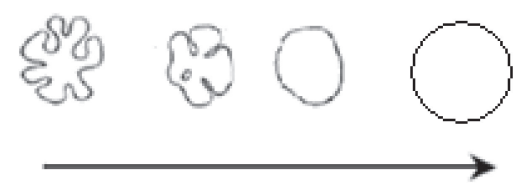

Fig. 8 The microstructure evolution mechanism of the solid $\mathrm{TiB}_{2} / 7075 \mathrm{Al}$ matrix composites with the different holding time at $630^{\circ} \mathrm{C}$.

particles can be conducive to improve the stability of semisolid slurry in near-liquidus thixoforming.

\section{Conclusions}

The results described in this work can be summarized as follows:

(1) $\mathrm{TiB}_{2} / 7075 \mathrm{Al}$ matrix composites are formed by in situ reaction in matrix melt. The microstructure becomes uniform rosette grains after adding $3 \% \mathrm{TiB}_{2}$, and the grain size shows a decreasing tendency with increasing of $\mathrm{TiB}_{2}$ particles. The morphology of grains become big dendrite grains when the $\mathrm{TiB}_{2}$ particles content are over $4.5 \%$.

(2) It can be got good globular grains with the different holding $7.5 \sim 10 \mathrm{~min}$ at $630^{\circ} \mathrm{C}$. The mean grain size can reach $94 \mu \mathrm{m}$, which is smaller than the as-cast microstructure. The phenomenon of necking and remelting of dendrite grains can be found at first, then rosette grains melt and shrink into the globular grain, finally the globular grains begin to melt with increasing of the holding time.

(3) The minimum grain size of $3 \% \mathrm{TiB}_{2} / 7075,4.5 \% \mathrm{TiB}_{2} /$ 7075 and $9 \% \mathrm{TiB}_{2} / 7075 \mathrm{Al}$ matrix composites are $88 \mu \mathrm{m}, 51 \mu \mathrm{m}$ and $69 \mu \mathrm{m}$ for $30 \mathrm{~min}, 20 \mathrm{~min}$ and 50 min, respectively. The $\mathrm{TiB}_{2}$ particles located in the grain boundary can hinder the $\mathrm{Al}$ atoms from diffusing within the semi-solid state of the $7075 \mathrm{Al}$ alloy and restrain $\alpha$-Al phase growth, but it can be conducive to improve the stability of semi-solid slurry in nearliquidus thixoforming.

\section{Acknowledgments}

This work was supported by the National Natural Science Foundation of China (Grant No. 51505051), the Scientific Research Staring Foundation of Chongqing University of Technology as Project number 2012ZD12, and Project Supported by Scientific and Technological Research Program of Chongqing Municipal Education Commission number KJ130813.

\section{REFERENCES}

1) D. B. Spencer, R. Mehrabian and M. C. Flemings: Metall. Trans. 3 (1972) 1925-1932.

2) M. C. Flemings: Metall. Trans. A 22 (1991) 957-981.

3) A. Neag, V. Favier, R. Bigot and M. Pop: J. Mater. Process. Tech. 212 (2012) 1472-1480.

4) A. Bolouri, M. Shahmiri and C. G. Kang: J. Alloy. Compd. 509 (2011) 402-408.

5) M. R. Rokni, A. Zarei-Hanzaki, H. R. Abedi and N. Haghdadi: Mater. Des. 36 (2012) 557-563.

6) F. Rikhtegar and M. Ketabchi: Mater. Des. 31 (2010) 3943-3948.

7) H. Mohammadi, M. Ketabchi and A. Kalaki: J. Mater. Eng. Perform. 20 (2011) 1256-1263.

8) Ł. Rogal, J. Dutkiewicz, H. V. Atkinson, L. Lityńska-Dobrzyńska, T. Czeppe and M. Modigell: Mater. Sci. Eng. A 580 (2013) 362-373.

9) G. M. Lu, J. Dong, J. Z. Cui and S. W. Luo: Acta Metall. Sin. 37 (2001) 1045-1048 (in Chinese).

10) H. M. Guo, X. J. Yang, J. X. Wang, B. Hu and G. L. Zhu: Trans. Nonferrous Met. Soc. China 20 (2010) 355-360.

11) U. A. Curle and G. Govender: Trans. Nonferrous Met. Soc. China 20 (2010) s832-s836.

12) B. Yang, W. M. Mao and X. J. Song: Trans. Nonferrous Met. Soc. China 23 (2013) 3592-3597.

13) G. S. Gan, B. Yang, H. C. Wu, J. Han, Q. Gao and C. H. Du: Mater. Trans. 53 (2012) 1178-1183.

14) G. S. Gan, Q. Gao, B. Yang and S. D. Gan: Adv. Mater. Res. 904 (2014) 50-53.

15) G. S. Gan and B. Yang: Trans. Nonferrous Met. Soc. China 24 (2014) 1133-1140 (in Chinese).

16) G. S. Gan and B. Yang: Rare Metals 38 (2014) 954-960 (in Chinese).

17) M. Wang, J. J. Gao and S. X. Chen: Foundry Technol. 28 (2007) 796799 (in Chinese).

18) T. E. Quested, A. L. Greer and P. S. Cooper: Mater. Sci. Forum 396402 (2002) 53-58.

19) A. L. Greer, A. M. Bunn, A. Tronche, P. V. Evans and D. J. Bristow: Acta Mater. 48 (2000) 2823-2835.

20) T. E. Quested and A. L. Greer: Acta Mater. 53 (2005) 4643-4653.

21) T. E. Quested and A. L. Greer: Acta Mater. 52 (2004) 3859-3868. 